\title{
Effects of enclosure size on activity and sleep of a hystricomorph rodent (Octodon degus)
}

\author{
ROBERT B. FISCHER and GARY F. MEUNIER \\ Ball State University, Muncie, Indiana 47603 \\ and

\section{P. J. O'DONOGHUE, D. L. RHODES, and A. M. SCHAFENAKER College of William and Mary, Williamsburg, Virginia 23185}

\begin{abstract}
Eight adult and eight infant degus were continuously observed over two 24-h sessions in order to determine the effects of large vs. small enclosure size on the stability of activity and sleep cycles. Behaviors were categorized into one of five mutually exclusive categories. Although the proportion of time spent engaging in sleep and other activities was not found to vary significantly, the circadian placement of activities by age and sex class was found to be altered as a function of enclosure size. These results are examined with reference to prevailing theories concerning the functions of sleep.
\end{abstract}

Although sleep appears to be ubiquitous at least among eutherian mammals (Chase, 1972), there exists considerable variability in the expression of the behavior. This variability is evident between species (Allison, Gerber, Breedlove, \& Dryden, 1977; Meddis, 1975; Zepelin \& Rechtschaffen, 1974) and within species as a function of age (Jouvet-Mounier, Astic, \& Lacote, 1970). Sleep has also been considered to be an aspect of instinctive regulation of cycles of behavior (Meddis, 1975; Webb, 1975). As such, sleep should exhibit less variability than other behaviors in an animal's repertoire. The degree of stereotypy is by no means clearly established. In large domestic animals, modifications of the environment via housing conditions or disturbances have been shown to alter some measure of sleep (Ruckebusch, 1975; Ruckebusch, Dallaire, \& Toutain, 1975). Variations of enclosure size have produced changes in the circadian placement of sleep of chipmunks as well (Estep, Fischer, \& Gore, 1978). Similar attempts to alter measures of sleep in rats have typically been unsuccessful (Van Twyver, Webb, Dube, \& Zackheim, 1973; Webb \& Friedman, 1971). To some extent, the susceptibility of a species to environmental effects of sleep cycles may relate to whether the species is a "good" sleeper, predators or species sleeping in well protected burrows or nests, or a "poor" sleeper, prey inhabiting exposed areas (Allison \& Van Twyver, 1970).

The present study examines sleep and activity in the degu (Octodon degus). The degu is a diurnal hystri-

This research was supported in part by funds from the Department of Psychology, College of William and Mary. We thank E. R. Harcum, P. Stocks, and T. Hanson for their assistance. Reprint requests should be directed to Robert B. Fischer, Department of Psychological Science, Ball State University, Muncie, Indiana 47306. comorph rodent, which in the wild inhabits a complex system of safe burrows (Fulk, 1976). Thus, the degu should be classified as a "good" sleeper, and the sleep patterns of these animals should be somewhat resistant to modifications of the environment. The degu is also characterized by giving birth to very precocial young. At birth, degus have a full coat of hair, have eyes and ears open, can move unassisted about the enclosure, and begin eating solid food at least by the 2 nd day of life. It might be expected that their sleep patterns approximate those of adults and would be resistant to environmental changes.

\section{METHOD}

The subjects were eight adult and eight infant degus (four males and four females in each group). All animals were descendants of laboratory stock. Adults were all at least 1 year of age and ranged in weight from 185 to $249 \mathrm{~g}$. The infants were 1 week of age at the beginning of the study, when they were separated and ranged in weight from 11.5 to $18.5 \mathrm{~g}$. Both the colony and testing room were maintained on a 14-h light, 10-h dark light-dark cycle. Food and water were freely available during the study. The animals were housed in cages of the same size as the small cages used during testing.

Twenty-four hours prior to data collection, the animals were moved to the testing room and individually placed into clear plastic cages containing corn cob bedding. Cages were designated either as small, measuring $27.5 \times 17.5 \times 12.5 \mathrm{~cm}$, or as large, measuring $47.5 \times 37.5 \times 20 \mathrm{~cm}$. Individual assignment to the cages was random, providing that age and sex assignment to large cages was balanced by a similar assignment to small cages. Four weeks later, the animals were tested again, counterbalancing for enclosure size. Observations were via one-way glass from a separate room. White noise was presented, beginning with the placement of the animals into the testing room. During the dark cycle, red incandescent bulbs provided a uniform, low-level (28-1x) illumination. During the light cycle, fluorescent bulbs provided uniform illumination $(700 \mathrm{~lx})$ at the level of the cages. 
Data were collected using an instantaneous sampling procedure (Altmann, 1974). The observers scanned each animal once per minute for 24 consecutive hours and categorized the observed activity into one of five mutually exclusive categories: sleep (behavioral quiescence with eyelid closure), quiet-inactive (quiescence with eyes open), general activity (walking, jumping, or other movements about the enclosure), ingestive (chewing or manipulating food items and, rarely, drinking), or grooming (scratching, licking, or other manipulation of the body). Percentage interobserver agreement ranged from $98 \%$ (sleep) to $86 \%$ (quiet-inactive).

\section{RESULTS}

Analyses for multidimensional contingency tables (Everitt, 1977) were performed on the data of Table 1. The percentage of time spent engaging in each behavioral category taken separately did not differ as a function of enclosure size. This result was also found for the total sleep time (sleep + quiet-inactive) under each condition $\left[\chi^{2}(4)=.15\right]$. The ratio of mean sleep to mean quietinactive did indicate a difference overall. Except for infant females, the smaller enclosure tended to increase time spent in quiet-inactive. These differences were significant for enclousre size $\left[\chi^{2}(3)=49.37, p<.001\right]$, sex $\left[\chi^{2}(3)=9.45, p<.025\right]$, and age $\left[\chi^{2}(3)=71.96\right.$, $\mathrm{p}<.001]$.

Table 1

Mean Percentage of Time, Mean Sleep-Quiet Ratios, and Mean Diurnal Ratios for Five Categories of Behavior by Sex and Age and for Large (L) and Small (S) Enclosures

\begin{tabular}{|c|c|c|c|c|c|c|}
\hline \multirow{2}{*}{$\begin{array}{c}\text { Behavioral } \\
\text { Category }\end{array}$} & \multirow[b]{2}{*}{$x^{2}$} & \multirow{2}{*}{$\begin{array}{l}\text { Age } \\
\text { Group }\end{array}$} & \multicolumn{2}{|c|}{ Male } & \multicolumn{2}{|c|}{ Female } \\
\hline & & & $\mathrm{L}$ & $\mathrm{S}$ & $\mathbf{L}$ & S \\
\hline \multicolumn{7}{|c|}{ Percentage of Time } \\
\hline Sleep & $9.36^{*}$ & $\begin{array}{l}\text { Adult } \\
\text { Infant }\end{array}$ & $\begin{array}{l}26 \\
29\end{array}$ & $\begin{array}{l}17 \\
25\end{array}$ & $\begin{array}{l}25 \\
21\end{array}$ & $\begin{array}{l}19 \\
41\end{array}$ \\
\hline $\begin{array}{l}\text { Quiet- } \\
\text { Inactive }\end{array}$ & $9.26^{*}$ & $\begin{array}{l}\text { Adult } \\
\text { Infant }\end{array}$ & $\begin{array}{l}38 \\
34\end{array}$ & $\begin{array}{l}44 \\
41\end{array}$ & $\begin{array}{l}35 \\
42\end{array}$ & $\begin{array}{l}43 \\
19\end{array}$ \\
\hline $\begin{array}{l}\text { General } \\
\text { Activity }\end{array}$ & $1.57^{*}$ & $\begin{array}{l}\text { Adult } \\
\text { Infant }\end{array}$ & $\begin{array}{l}29 \\
23\end{array}$ & $\begin{array}{l}32 \\
24\end{array}$ & $\begin{array}{l}34 \\
25\end{array}$ & $\begin{array}{l}31 \\
18\end{array}$ \\
\hline Ingestive & $4.62 *$ & $\begin{array}{l}\text { Adult } \\
\text { Infant }\end{array}$ & $\begin{array}{r}6 \\
11\end{array}$ & $\begin{array}{l}5 \\
8\end{array}$ & $\begin{array}{r}5 \\
10\end{array}$ & $\begin{array}{r}5 \\
20\end{array}$ \\
\hline Grooming & $2.88^{*}$ & $\begin{array}{l}\text { Adult } \\
\text { Infant }\end{array}$ & $\begin{array}{l}1 \\
4\end{array}$ & $\begin{array}{l}3 \\
2\end{array}$ & $\begin{array}{l}1 \\
2\end{array}$ & $\begin{array}{l}3 \\
2\end{array}$ \\
\hline \multicolumn{7}{|c|}{ Mean Sleep/Mean Quiet-Inactive } \\
\hline & $23.12 \dagger$ & $\begin{array}{l}\text { Adult } \\
\text { Infant }\end{array}$ & $\begin{array}{l}.67 \\
.83\end{array}$ & $\begin{array}{l}.37 \\
.61\end{array}$ & $\begin{array}{l}.70 \\
.51\end{array}$ & $\begin{array}{r}.43 \\
2.13\end{array}$ \\
\hline \multicolumn{7}{|c|}{ Diurnal Ratio } \\
\hline Sleep & $194.91 \dagger$ & $\begin{array}{l}\text { Adult } \\
\text { Infant }\end{array}$ & $\begin{array}{l}.21 \\
.48\end{array}$ & $\begin{array}{l}.12 \\
.22\end{array}$ & $\begin{array}{l}.09 \\
.06\end{array}$ & $\begin{array}{l}.18 \\
.47\end{array}$ \\
\hline $\begin{array}{l}\text { Quiet- } \\
\text { Inactive }\end{array}$ & $74.09 \dagger$ & $\begin{array}{l}\text { Adult } \\
\text { Infant }\end{array}$ & $\begin{array}{l}1.73 \\
1.63\end{array}$ & $\begin{array}{l}1.21 \\
1.14\end{array}$ & $\begin{array}{l}1.01 \\
1.67\end{array}$ & $\begin{array}{r}.98 \\
1.55\end{array}$ \\
\hline $\begin{array}{l}\text { General } \\
\text { Activity }\end{array}$ & $40.93 \dagger$ & $\begin{array}{l}\text { Adult } \\
\text { Infant }\end{array}$ & $\begin{array}{l}.99 \\
.61\end{array}$ & $\begin{array}{l}1.00 \\
1.76\end{array}$ & $\begin{array}{r}1.74 \\
.99\end{array}$ & $\begin{array}{l}1.29 \\
1.14\end{array}$ \\
\hline Ingestive & $21.76 \dagger$ & $\begin{array}{l}\text { Adult } \\
\text { Infant }\end{array}$ & $\begin{array}{l}.82 \\
.91\end{array}$ & $\begin{array}{r}1.37 \\
.69\end{array}$ & $\begin{array}{r}.89 \\
1.08\end{array}$ & $\begin{array}{l}2.03 \\
1.23\end{array}$ \\
\hline Grooming & $1.36^{*}$ & $\begin{array}{l}\text { Adult } \\
\text { Infant }\end{array}$ & $\begin{array}{r}1.38 \\
.34 \\
\end{array}$ & $\begin{array}{l}.68 \\
.83\end{array}$ & $\begin{array}{r}3.75 \\
.51 \\
\end{array}$ & $\begin{array}{r}.60 \\
1.24\end{array}$ \\
\hline
\end{tabular}

Note $-\chi^{2}$ values indicate results of contingency table analysis for overall main effects (df $=4$ ). $\quad *$ Nonsignificant. $\quad t p<.001$.
The diurnal ratio is a measure of the circadian placement of a behavior, calculated by dividing the total activity that occurs during the light by the total dark activity. Inferential analysis employed whole-number proportions of activity occurring during the light phase. Significant main effects were found for all behavioral categories except for grooming. Specific comparisons indicated that circadian differences in these ratios did not differ significantly as a function of sex class. This analysis did indicate differences due to enclosure size [sleep: $\chi^{2}(3)=16.4, p<.001$; quiet: $\chi^{2}(3)=10.21$, $\mathrm{p}<.025$; activity: $\chi^{2}(3)=23.24, \mathrm{p}<.001$; and ingestive: $\chi^{2}(3)=13.27, \mathrm{p}<.01$ ] and age [sleep: $\chi^{2}(3)=$ $38.94, \mathrm{p}<.001$; quiet: $\chi^{2}(3)=64.23, \mathrm{p}<.001$; activity: $\chi^{2}(3)=16.22, p<.01$; and ingestive: $\chi^{2}(3)=9.17$, $\mathrm{p}<.05]$.

\section{DISCUSSION}

The results of this study indicate that some aspects of sleep may indeed be susceptible to environmental alterations, even in a presumably "good" sleeper. The total proportion of time spent sleeping and engaging in the other behaviors examined appears to be resistant to environmental changes. The time budgets of these animals appear to be stable. Enclosure size produced an effect on the phase of the light cycle during which a behavior is likely to occur. For males, a small enclosure induced a shift to expending a greater proportion of time in sleep and quietinactive during the dark phase. Females exhibited a similar trend for quiet-inactive, but an opposite trend for sleep. Infant degus overall seem to engage in a greater proportion of sleep during the light phase than do adult animals. Infants also engage in a greater amount of quiet-inactive. These results would lend support to sleep's acting as an enforced time-out (Meddis, 1975), reducing a young animal's exposure in the wild to predation and temperature extremes. Adult animals were indeed more active during the light phase of the cycle. This is true even though the percentage of time devoted to these activities over a $24-\mathrm{h}$ period did not differ significantly by either age or sex class.

Additional work is needed to further investigate the effects of environmental modifications on sleep and activity in rodent species other than those commonly encountered in the laboratory. This is particularly true for predominately diurnal species, such as the degu, which may be more susceptible to the effects of environmental changes (DeCoursey, 1972; Estep et al., 1978).

\section{REFERENCES}

Allison, T., Gerber, S. D., Breedlove, S. M., \& Dryden, G. L. A behavioral and polygraphic study of sleep in the shrews Suncus murinus, Blarina brevicauda, and Cryptotis parva. Behavioral Biology, 1977, 20, 354-366.

Allison, T., \& Van Twyver, H. The evolution of sleep. Natural History, 1970, 79, 56-65.

Altmann, J. Observational study of behavior: Sampling methods. Behavior, 1974, 49, 227-267.

Chase, M. H. (Ed.). The sleeping brain, perspectives in the brain sciences (Vol. 1). Los Angeles: Brain Information Service/Brain Research Institute, UCLA, 1972.

DeCoursey, P. L. LD ratios and the entrainment of circadian activity in a nocturnal and diurnal rodent. Journal of Comparative Physiology, 1972, 78, 221-235.

Estep, D. Q., Fischer, R. B., \& Gore, W. T. Effects of enclosure size and complexity on the activity and sleep of the eastern chipmunk Tamias striatus. Behavioral Biology, 1978, 23, 249-253. 
Everitt, B. S. The analysis of contingency tables. London: Chapman \& Hall, 1977.

FulK, G. W. Notes on the activity, reproduction, and social behavior of Octodon degus. Journal of Mammalogy, 1976, 57, 495-505.

Jouvet-Mounier, D., Astic, L., \& Lacote, D. Ontogenesis of the states of sleep in rat, cat, and guinea pig during the first postnatal month. Developmental Psychobiology, 1970, 216-239.

Meddis, R. On the function of sleep. Animal Behavior, 1975, 23, 676-691.

RUCKebUSCH, Y. The hypnogram as an index of adaptation of farm animals to change in their environment. Applied Animal Ethology, 1975, 2, 3-18.

Ruckebusch, Y., Dallaire, A., \& Toutain, P. L. Sleep patterns and environmental stimuli. In P. Levin \& W. P.
Koella (Eds.), Sleep 1974. Second European Congress on Sleep Research. Rome: 1975.

Van Twyver, H., Webb, W. B., Dube, M., \& Zackheim, M. Effects of environmental and strain differences on EEG and behavioral measurement of sleep. Behavioral Biology, 1973, 9, 105-110.

Wевв, W. B. Sleep, the gentle tyrant. Englewood Cliffs, N.J: Prentice-Hall, 1975.

Webb, W. B., \& Friedman, J. Attempts to modify the sleep patterns of the rat. Physiology \& Behavior, 1971, 6, 459-460.

Zepelin, H., \& Rechtschaffen, A. Mammalian sleep, longevity, and energy metabolism. Brain Behavior and Evolution, 1974, $10,425-470$.

(Received for publication August 14, 1980.) 